\title{
Combustion Synthesis of $\mathrm{Si}_{3} \mathrm{~N}_{4}-\mathrm{BN}-\mathrm{SiC}$ Composites by in-situ Introduction of $\mathrm{BN}$ and $\mathrm{SiC}$
}

\author{
ZHANG Ye ${ }^{1,2}$, YAO Dongxu ${ }^{1}$, ZUO Kaihui ${ }^{1}$, XIA Yongfeng ${ }^{1}$, YIN Jinwei $^{1}$, ZENG Yuping ${ }^{1}$ \\ (1. State Key Laboratory of High Performance Ceramics and Superfine Microstructure, Shanghai Institute of Ceramics, Chinese \\ Academy of Sciences, Shanghai 200050, China; 2. Center of Materials Science and Optoelectronics Engineering, University of \\ Chinese Academy of Sciences, Beijing 100049, China)
}

\begin{abstract}
Si}_{3} \mathrm{~N}_{4}-\mathrm{BN}-\mathrm{SiC}$ composites present desirable potential for engineering applications because of their improved mechanical properties and oxidation resistance. In present work, $\mathrm{Si}_{3} \mathrm{~N}_{4}-\mathrm{BN}-\mathrm{SiC}$ composites were successfully fabricated by combustion synthesis using $\mathrm{Si}, \mathrm{Si}_{3} \mathrm{~N}_{4}$ diluent, $\mathrm{B}_{4} \mathrm{C}$, and $\mathrm{Y}_{2} \mathrm{O}_{3}$ as initial powders. $\mathrm{BN}$ and $\mathrm{SiC}$ were in situ introduced into $\mathrm{Si}_{3} \mathrm{~N}_{4}$ ceramics by the reaction between $\mathrm{Si}, \mathrm{B}_{4} \mathrm{C}$, and $\mathrm{N}_{2}$ gas. The obtained $\mathrm{Si}_{3} \mathrm{~N}_{4}-\mathrm{BN}-\mathrm{SiC}$ composites were composed of elongated $\beta$ - $\mathrm{Si}_{3} \mathrm{~N}_{4}$ matrix and hollow spherical composites. The formation mechanism of the hollow spherical microstructure was investigated. The results show that the generated $\mathrm{SiC}$ and $\mathrm{BN}$ particles and glass phase cover on the raw materials, and hollow spherical microstructure is formed when raw particles are depleted. Furthermore, the impacts of $\mathrm{B}_{4} \mathrm{C}$ content on the mechanical properties of $\mathrm{Si}_{3} \mathrm{~N}_{4}$ - $\mathrm{BN}-\mathrm{SiC}$ composites were investigated in detail. The in-situ introduction of $\mathrm{BN}$ and $\mathrm{SiC}$ is beneficial to improving mechanical properties of the composites to some extent. Finally, $\mathrm{Si}_{3} \mathrm{~N}_{4}-\mathrm{BN}-\mathrm{SiC}$ composites with bending strength of 28-144 $\mathrm{MPa}$, fracture toughness of 0.6-2.3 MPa $\cdot \mathrm{m}^{1 / 2}$, Young's modulus of $17.4-54.5 \mathrm{GPa}$, and porosity of $37.7 \%-51.8 \%$ were obtained for the samples with $0-20 \%$ (in mass) $\mathrm{B}_{4} \mathrm{C}$ addition.
\end{abstract}

Key words: combustion synthesis; $\mathrm{Si}_{3} \mathrm{~N}_{4}-\mathrm{BN}-\mathrm{SiC}$ composites; in situ introduction; phase compositions; hollow sphere; formation mechanism

Silicon nitride $\left(\mathrm{Si}_{3} \mathrm{~N}_{4}\right)$ ceramics have been extensively used as structural and/or functional components in various engineering fields such as filtration, aerospace, and membrane support. It possesses low thermal expansion coefficient, excellent mechanical properties, good thermal shock resistance, and high chemical stability due to its strongly covalent bonds between atoms ${ }^{[1-3]}$. Several technologies can be used to fabricate $\mathrm{Si}_{3} \mathrm{~N}_{4}$ ceramics, including pressureless sintering ${ }^{[4-5]}$, reactive sintering ${ }^{[6-7]}$, carbothermal synthesis ${ }^{[8]}$, and combustion synthesis $(\mathrm{CS})^{[9-10]}$. Among these approaches, combustion synthesis can achieve rapid and low-cost fabrication of $\mathrm{Si}_{3} \mathrm{~N}_{4}$ ceramics by the self-propagating of combustion waves using $\mathrm{Si}$ as starting material ${ }^{[9]}$.

Compared with $\mathrm{Si}_{3} \mathrm{~N}_{4}$ ceramics, $\mathrm{Si}_{3} \mathrm{~N}_{4}-\mathrm{BN}-\mathrm{SiC}$ composites present some improved properties such as lower dielectric constant, lower thermal expansion coefficient, and higher flexural strength, which draws attractive atte- ntions in engineering applications ${ }^{[11-12]}$. The traditional introduction way of an additional phase is to add the required phase into the initial powders ${ }^{[13]}$. However, the introduced phase is difficult to disperse homogeneously into the sintered product. In-situ introduction can solve this difficulty and achieve good interface bonding between the matrix and introduced phases ${ }^{[14]}$. But investigations involving the in-situ introduction of $\mathrm{BN}$ or $\mathrm{SiC}$ into $\mathrm{Si}_{3} \mathrm{~N}_{4}$ matrix are limited. Kusunose et al. ${ }^{[15]}$ reported the preparation of $\mathrm{Si}_{3} \mathrm{~N}_{4} / \mathrm{BN}$ nanocomposites by hot-pressing the t-BN coated $\alpha-\mathrm{Si}_{3} \mathrm{~N}_{4}$ powders, t-BN was in situ synthesized by the reducing reaction between boric acid and urea. Zheng et al. ${ }^{[16]}$ used $\mathrm{B}_{4} \mathrm{C}$ and $\mathrm{Si}$ as raw materials to prepare h-BN-SiC composites via their combustion reaction at high-pressure $\mathrm{N}_{2}$ gas (60-120 MPa). Inspired by the above work, present study attempts to in situ introduce $\mathrm{BN} / \mathrm{SiC}$ into $\mathrm{Si}_{3} \mathrm{~N}_{4}$ matrix by $\mathrm{B}_{4} \mathrm{C}$ addition. The microstructural evolution of the in-situ fabricated

Received date: 2021-07-05; Revised date: 2021-09-06; Published online: 2021-09-27

Foundation item: National Key R\&D Program of China (2018YFF01013605); National Natural Science Foundation of China (51902327)

Biography: ZHANG Ye (1994-), male, PhD candidate. E-mail: zhangyezn@student.sic.ac.cn 张 叶(1994-), 男, 博士研究生. E-mail: zhangyezn@student.sic.ac.cn

Corresponding author: ZENG Yuping, male, professor. E-mail: yuping-zeng@mail.sic.ac.cn 曾宇平, 研究员. E-mail: yuping-zeng@mail.sic.ac.cn 
$\mathrm{BN} / \mathrm{SiC}$ and its effects on the properties of the sintered $\mathrm{Si}_{3} \mathrm{~N}_{4}-\mathrm{BN}-\mathrm{SiC}$ composites is studied.

\section{Experimental}

The initial powders were Si powder (Peixian Tiannayuan Silicon Materials Co., Ltd., Jiangsu, China; purity $\geqslant$ $99.99 \% ; d_{50}=4.1 \mu \mathrm{m}$ ), $\mathrm{Si}_{3} \mathrm{~N}_{4}$ powder (Yantai Tomley Hi-Tech Advanced Materials Co., Ltd., Shandong, China; purity $\geqslant 99.9 \%$; $\alpha$-phase content $=42.3 \%$ (in mass); $d_{50}=$ $22 \mu \mathrm{m}$ ), $\mathrm{B}_{4} \mathrm{C}$ powder (Dalian Jinma Boron Technology Group Co., Ltd, Shandong, China; purity $\geqslant 99.99 \% ; d_{50}=$ $1.5 \mu \mathrm{m}$ ), and $\mathrm{Y}_{2} \mathrm{O}_{3}$ powder (Yuelong New Material Co., Ltd, Shanghai, China; purity $\geqslant 99.999 \% ; d_{50}=5.04 \mu \mathrm{m}$ ). The weight ratio of initial powders was determined as $\mathrm{Si}$ : $\mathrm{Si}_{3} \mathrm{~N}_{4}: \mathrm{B}_{4} \mathrm{C}: \mathrm{Y}_{2} \mathrm{O}_{3}=40:(60-x): x: 2(x=0,5,10,15,20)$. The samples were named $\mathrm{SBC} 00, \mathrm{SBC} 05, \mathrm{SBC} 10$, $\mathrm{SBC} 15$, and $\mathrm{SBC} 20$ according to the weight ratio of $\mathrm{B}_{4} \mathrm{C}$, respectively. To obtain homogeneous mixtures, the ceramic powders were ball-milled for $3 \mathrm{~h}$ in ethyl alcohol with a ball/charge weight ratio of $2: 1$. After dried and sieved through a $150 \mu \mathrm{m}$ (100 mesh) screen, each homogeneous mixture was cold-pressed into a rectangular compact ( $40 \mathrm{~mm} \times 40 \mathrm{~mm} \times 10 \mathrm{~mm}$ ) at $10 \mathrm{MPa}$. The obtained compact was immersed into a powder bed (homogeneous mixture of $40 \% \mathrm{Si}$ and $60 \% \mathrm{Si}_{3} \mathrm{~N}_{4}$ (in mass)) and ignited under $5 \mathrm{MPa} \mathrm{N}_{2}$ atmosphere. Schematic diagram of the reactor and detailed preparation process was mentioned in previous work ${ }^{[17]}$.

The reaction temperature was obtained from the W-Re $5 / 26$ thermocouple immersed into the powder bed. Rectangular bars with the dimensions of $3.0 \mathrm{~mm} \times 4.0 \mathrm{~mm} \times 36.0 \mathrm{~mm}$ were prepared to measure the bending strength and Young's modulus by three-point bending method (Instron-3443, Instron, USA). Fracture toughness was tested by single-edge notched beam method (SEBN) on pre-notched bars $(3.0 \mathrm{~mm} \times 6.0 \mathrm{~mm} \times 30.0 \mathrm{~mm})$. The microstructure of the sample was observed by scanning electron microscope (SU-1000, Hitachi, Japan) and transmission electron microscope (JEM-2100F, JEOL Company, Japan). The phase composition of the sample was performed by XRD (Diffractor meter D8, Bruker, Germany), and the content of each crystalline phase was calculated based on the XRD results. The open porosity of sintered sample was determined by the Archimedes method in the distilled water. The total porosity $(P)$ was calculated from the measured bulk density $\left(\rho_{\mathrm{b}}\right)$, theoretical density ( $\rho$, calculated based on the phase content of each phase) using following equation: $P=1-\rho_{\mathrm{b}} / \rho$.

\section{Results and disscusion}

The possible reactions during the fabrication process are shown in Eq. (1-2). Both the reactions are exothermic, but the adiabatic temperature of reaction (2) is reported to be lower than that of reaction $(1)^{[18-19]}$. It meets the experimental results as shown in Table 1, the measured reaction temperature decreases from $1850{ }^{\circ} \mathrm{C}$ to $1765{ }^{\circ} \mathrm{C}$ with the increase of $\mathrm{B}_{4} \mathrm{C}$ content. Meanwhile, the reaction time increases with the $\mathrm{B}_{4} \mathrm{C}$ content increasing, it can be ascribed to the generation of $\mathrm{SiC}$ and $\mathrm{BN}$ which restrain the propagating of combustion wave as an inert phase.

$$
\begin{gathered}
3 \mathrm{Si}(\mathrm{s})+2 \mathrm{~N}_{2}(\mathrm{~g})=\mathrm{Si}_{3} \mathrm{~N}_{4}(\mathrm{~s}) \\
\Delta G^{\theta}=-725.615 \mathrm{~kJ} / \mathrm{mol} \\
\mathrm{Si}(\mathrm{s})+2 \mathrm{~N}_{2}(\mathrm{~g})+\mathrm{B}_{4} \mathrm{C}(\mathrm{s})=\mathrm{SiC}(\mathrm{s})+4 \mathrm{BN}(\mathrm{s}) \\
\Delta G^{\theta}=-914.459 \mathrm{~kJ} / \mathrm{mol}
\end{gathered}
$$

Fig.1 displays the phase identification of the obtained composites. The detected crystalline phase of sample $\mathrm{SBC} 00$ without $\mathrm{B}_{4} \mathrm{C}$ is $\beta-\mathrm{Si}_{3} \mathrm{~N}_{4}$. With the increase of $\mathrm{B}_{4} \mathrm{C}$ content, the content of $\mathrm{BN}$ and $\mathrm{SiC}$ increase evidently. Besides, it is worth noting that peak broadening is observed for $\mathrm{BN}$, which reveals that its crystallization is unsatisfactory in such a rapid combustion process. When $\mathrm{B}_{4} \mathrm{C}$ content is equal to or greater than $10 \%$ (in mass), residual $\mathrm{Si}$ is detected, which reveals that the nitridation of $\mathrm{Si}$ is suppressed by the newly formed $\mathrm{BN}$ and $\mathrm{SiC}$. Meanwhile, residual $\alpha-\mathrm{Si}_{3} \mathrm{~N}_{4}$ is also detected for samples prepared with high $\mathrm{B}_{4} \mathrm{C}$ addition. The fabrication mechanism of $\mathrm{Si}_{3} \mathrm{~N}_{4}$ ceramics is primarily controlled by the dissolution of $\alpha-\mathrm{Si}_{3} \mathrm{~N}_{4}$ and precipitation of $\beta-\mathrm{Si}_{3} \mathrm{~N}_{4}{ }^{[20]}$. The decreasing reaction temperature as shown in Table 1

Table 1 Reaction parameters during combustion synthesis and physical properties of the sintered samples with different $\mathrm{B}_{4} \mathrm{C}$ contents

\begin{tabular}{cccccccc}
\hline Sample & $\begin{array}{c}\text { Reaction } \\
\text { temperature } /{ }^{\circ} \mathrm{C}\end{array}$ & $\begin{array}{c}\text { Reaction } \\
\text { time/s }\end{array}$ & $\begin{array}{c}\text { Open } \\
\text { porosity/\% }\end{array}$ & $\begin{array}{c}\text { Total } \\
\text { porosity/\% }\end{array}$ & $\begin{array}{c}\text { Bending } \\
\text { strength/MPa }\end{array}$ & $\begin{array}{c}\text { Fracture toughness/ } \\
\left(\mathrm{MPa} \cdot \mathrm{m}^{1 / 2}\right)\end{array}$ & $\begin{array}{c}\text { Young's } \\
\text { modulus/GPa }\end{array}$ \\
\hline SBC00 & $(1850 \pm 15)$ & $(16 \pm 3)$ & $(51.8 \pm 1.0)$ & 52.0 & $(120 \pm 12.0)$ & $(2.2 \pm 0.4)$ & $(49.5 \pm 1.6)$ \\
SBC05 & $(1825 \pm 20)$ & $(18 \pm 5)$ & $(47.3 \pm 0.5)$ & 48.5 & $(144 \pm 8.4)$ & $(2.3 \pm 0.2)$ & $(54.5 \pm 1.7)$ \\
SBC10 & $(1795 \pm 12)$ & $(21 \pm 2)$ & $(43.3 \pm 0.6)$ & 47.5 & $(108 \pm 5.0)$ & $(1.7 \pm 0.2)$ & $(46.2 \pm 3.0)$ \\
SBC15 & $(1778 \pm 20)$ & $(26 \pm 5)$ & $(42.3 \pm 0.5)$ & 46.9 & $(30 \pm 7.4)$ & $(0.7 \pm 0.2)$ & $(18.5 \pm 2.1)$ \\
SBC20 & $(1765 \pm 14)$ & $(30 \pm 3)$ & $(37.7 \pm 1.7)$ & 45.2 & $(28 \pm 3.9)$ & $(0.6 \pm 0.1)$ & $(17.4 \pm 1.2)$ \\
\hline
\end{tabular}




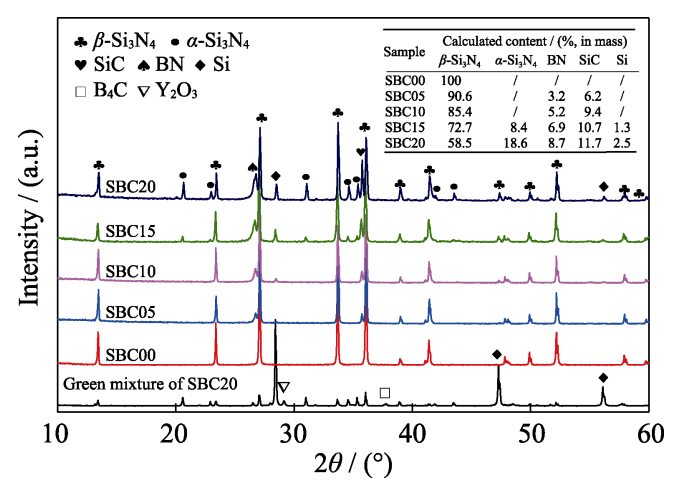

Fig. 1 XRD patterns of the green mixture and sintered samples with varied $\mathrm{B}_{4} \mathrm{C}$ contents

is unfavorable to the phase transition from $\alpha-\mathrm{Si}_{3} \mathrm{~N}_{4}$ to $\beta$-Si $\mathrm{N}_{4}$, which results in the residual $\alpha-\mathrm{Si}_{3} \mathrm{~N}_{4}$ in materials. Besides, the formed $\mathrm{BN}$ and $\mathrm{SiC}$ disperse in the liquid phase and restrain the mass transport, which is also a significant factor leading to the residual $\alpha-\mathrm{Si}_{3} \mathrm{~N}_{4}$.

Fig. 2 shows the microstructure of green mixture of SBC20, and fracture-surface microstructure of the CSfabricated specimens with varied $\mathrm{B}_{4} \mathrm{C}$ contents. It could be seen that the microstructure varies evidently after CS process. Before CS process, the green mixture is particulate. After CS process, sample SBC00 without $\mathrm{B}_{4} \mathrm{C}$ is composed of interlocking $\beta$ - $\mathrm{Si}_{3} \mathrm{~N}_{4}$ grains with high aspect ratio. $\mathrm{As}_{4} \mathrm{C}$ is added to the raw materials, the development of $\beta-\mathrm{Si}_{3} \mathrm{~N}_{4}$ grains is evidently inhibited. Average aspect ratio of $\beta-\mathrm{Si}_{3} \mathrm{~N}_{4}$ grains decreases significantly with
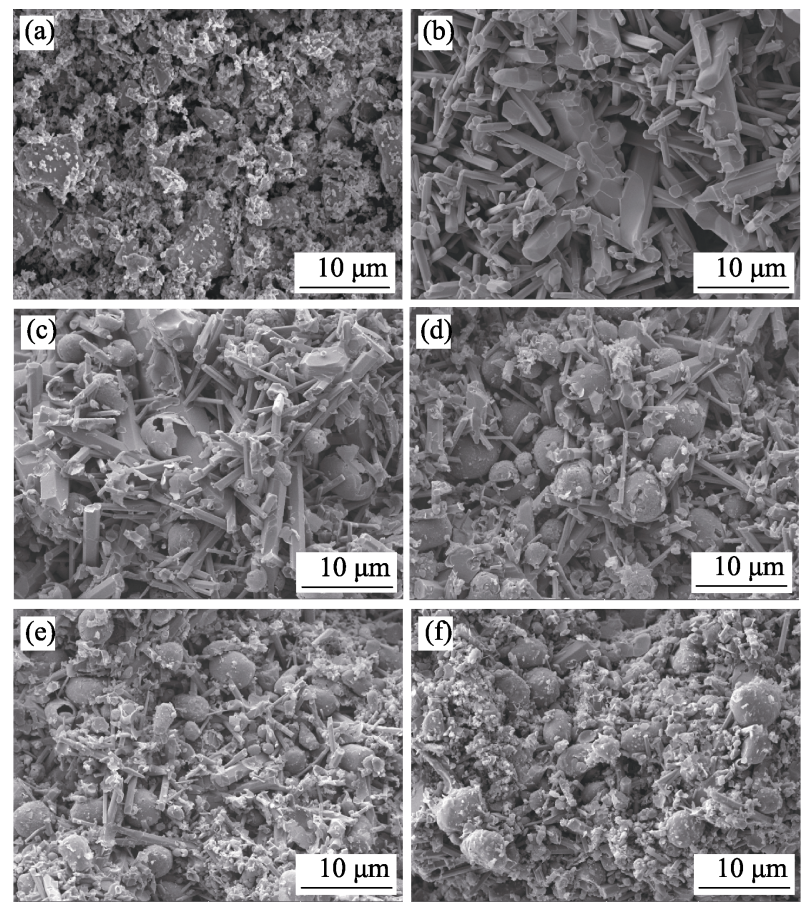

Fig. 2 Microstructure of green mixture of SBC20 (a) and fracturesurface microstructures of the CS-fabricated specimens with $\mathrm{B}_{4} \mathrm{C}$ contents at (b) 0 , (c) $5 \%$, (d) $10 \%$, (e) $15 \%$, and (f) $20 \%$ (in mass) the increase of $\mathrm{B}_{4} \mathrm{C}$ content, almost no elongated grains can be observed when $\mathrm{B}_{4} \mathrm{C}$ content is $20 \%$ (in mass). Furthermore, hollow spherical microstructure is observed for the samples prepared with $\mathrm{B}_{4} \mathrm{C}$ addition. The hollow spheres have very thin wall and evident micropores on their surfaces when $\mathrm{B}_{4} \mathrm{C}$ content is $5 \%$ (in mass). With the increase of $\mathrm{B}_{4} \mathrm{C}$ content, the thickness of the wall increases and closed hollow sphere is gradually formed. This hollow spherical microstructure is different from that of flaky $\mathrm{BN}-\mathrm{SiC}$ composites prepared at $60-120 \mathrm{MPa} \mathrm{N}_{2}$ gas $^{[16]}$, which illustrates that the microstructure of $\mathrm{Si}_{3} \mathrm{~N}_{4}-\mathrm{BN}-\mathrm{SiC}$ composites is evidently influenced by the $\mathrm{N}_{2}$ gas pressure.

The properties of the sintered samples are shown in Table 1, the open porosity of sample SBC00 is $51.8 \%$. With the increase of $\mathrm{B}_{4} \mathrm{C}$ content, the open porosity of the sample decreases apparently. When the $\mathrm{B}_{4} \mathrm{C}$ content is $20 \%$ (in mass), the open porosity of the obtained $\mathrm{Si}_{3} \mathrm{~N}_{4}-\mathrm{BN}-\mathrm{SiC}$ composites is $37.7 \%$. The significant decrease in porosity can be attributed to the higher volume expansion $(170 \%)$ of reaction (2) than that of nitridation of $\mathrm{Si}(21.2 \%)^{[16]}$, more pores are filled by the generated $\mathrm{SiC}$ and $\mathrm{BN}$ grains. However, the calculated total porosity based on the XRD results is higher than open porosity, especially for samples prepared with higher $\mathrm{B}_{4} \mathrm{C}$ content. On one hand, closed pores are formed with increasing addition of $\mathrm{B}_{4} \mathrm{C}$ as discussed above. On the other hand, $\mathrm{B}_{4} \mathrm{C}$ might form glass phase with native $\mathrm{SiO}_{2}$ film and $\mathrm{Y}_{2} \mathrm{O}_{3}$ during the high-temperature CS process, the theoretical density calculated based on the XRD results is higher than the actual value of sample, thus leading to the increasing total porosity. This behavior could be proven from the calculated content of each phase by XRD. According to the law of conservation of mass of reaction (2), the content of the generated $\mathrm{BN}$ and $\mathrm{SiC}$ should be higher than the calculated content. It illustrates that $\mathrm{B}_{4} \mathrm{C}$ partially forms glass phase instead of $\mathrm{BN}$ and $\mathrm{SiC}$ after CS process, which could not be detected by XRD.

To investigate the reaction mechanism of the CS process, transmission electron microscope (TEM), high-resolution transmission electron microscope (HRTEM), energy dispersive spectroscope (EDS) analysis, and selected area electron diffraction (SAED) are conduct on sample SBC10 and the results are shown in Fig. 3. The results demonstrate that the hollow sphere is a mixture of polycrystalline phase and amorphous phase. The crystalline phase should be $\mathrm{BN}$ and $\mathrm{SiC}$ combining the XRD analysis in Fig. 1. The amorphous phase consists of multiple elements including $\mathrm{B}, \mathrm{C}, \mathrm{Si}, \mathrm{N}$, and a little amount of $\mathrm{O}$. On one hand, it has the characteristics of SiBCN ceramics ${ }^{[21]}$. It is well known that $\mathrm{SiBCN}$ ceramics have two compositions of amorphous $\operatorname{SiC}_{x} \mathrm{~N}_{4-x}(x=1-4)$ and graphite-like $\mathrm{BN}(\mathrm{C})^{[22]}$. The above-mentioned broadening of $\mathrm{BN}$ peak derives from the formation of amorphous $\mathrm{BN}(\mathrm{C})$. On the other hand, the amorphous phase contains evident glass phase 

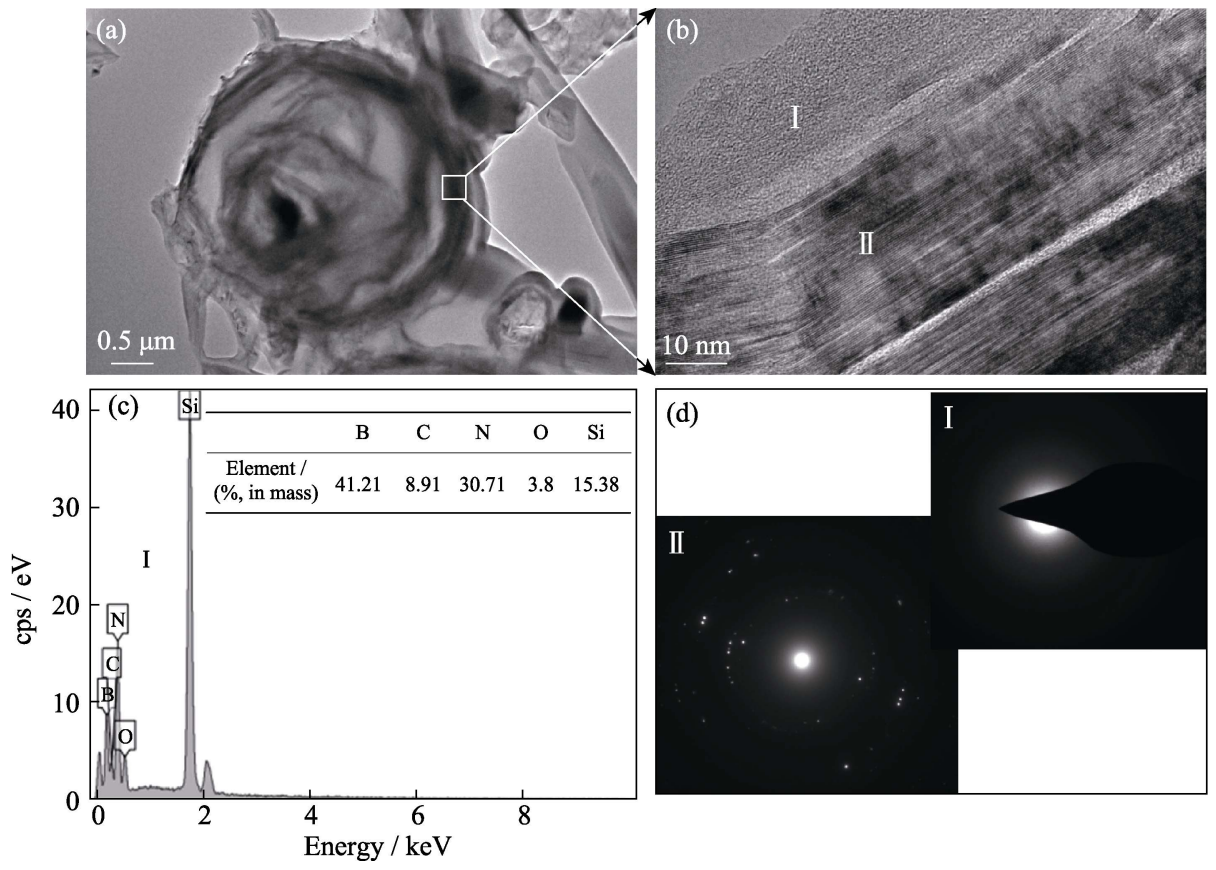

Fig. 3 (a) TEM image, (b) HRTEM image, (c) EDS analysis, and (d) SAED images of sample SBC10

combining the SEM image. The formation of the hollow spherical microstructure may originate from the comparatively low $\mathrm{N}_{2}$ gas pressure and the formation of glass phase. At the initial stage of the combustion reaction, eutectic liquid phase, and small $\mathrm{BN}$ and $\mathrm{SiC}$ particles are formed and cover the surfaces of raw particles, but the small BN flakes could not grow up because of the low $\mathrm{N}_{2}$ gas pressure and restriction of liquid phase. As the reaction proceeding, the newly formed products continue to cover the surfaces thus forming hollow spheres when raw particles are depleted. Ultimately, eutectic liquid phase forms glass phase during the rapid cooling of CS process.

As listed in Table 1, the mechanical properties of the obtained $\mathrm{Si}_{3} \mathrm{~N}_{4}-\mathrm{BN}-\mathrm{SiC}$ composites fluctuate with different contents of $\mathrm{B}_{4} \mathrm{C}$ addition. Compared to the monolithic $\mathrm{Si}_{3} \mathrm{~N}_{4}$ ceramics, the composites prepared with $5 \%$ (in mass) $\mathrm{B}_{4} \mathrm{C}$ has higher bending strength of $144 \mathrm{MPa}$ and higher Young's modulus of $54.5 \mathrm{GPa}$. These improvements mainly result from the decrease of porosity of the sample according to the well-known negative relationship between bending strength and porosity of porous material ${ }^{[23]}$. Additionally, the generated $\mathrm{BN}$ and $\mathrm{SiC}$ grains may also benefit the mechanical properties of composites because of their pinning effects within the grain boundary. But the fracture toughness of composites doesnot show apparent increase. It could be ascribed to the introductions of $\mathrm{BN}$ and $\mathrm{SiC}$ grains, resulting in more lattice defects in $\mathrm{Si}_{3} \mathrm{~N}_{4}$ grains. The elongated $\mathrm{Si}_{3} \mathrm{~N}_{4}$ grains become new crack sources, which is unfavorable to the fracture toughness of composites. With the further increase of $\mathrm{B}_{4} \mathrm{C}$ content, the porosity of the obtained $\mathrm{Si}_{3} \mathrm{~N}_{4}$ $\mathrm{BN}-\mathrm{SiC}$ composites decreases continuously from $47.3 \%$ to $37.7 \%$, but their mechanical properties, including bending strength, Young's modulus, and fracture tough- ness, degrade sharply. These behaviors indicate that the variation of microstructure is the predominated factor degrading the mechanical properties. On the one hand, the introduction of hollow spheres instead of elongated $\mathrm{Si}_{3} \mathrm{~N}_{4}$ grains presents lower mechanical properties than that of $\mathrm{Si}_{3} \mathrm{~N}_{4}$ ceramics with elongated morphology. On the other hand, the growth of $\mathrm{Si}_{3} \mathrm{~N}_{4}$ grain is restrained because of the introduction of $\mathrm{B}_{4} \mathrm{C}$ and the consequent generation of $\mathrm{BN}$ and $\mathrm{SiC}$. Therefore, the degraded average aspect ratio is also a significant factor decreasing the mechanical properties of the $\mathrm{Si}_{3} \mathrm{~N}_{4}-\mathrm{BN}-\mathrm{SiC}$ composites according to the theory of crack deflection ${ }^{[24]}$.

\section{Conclusion}

In this research, $\mathrm{Si}_{3} \mathrm{~N}_{4}-\mathrm{BN}-\mathrm{SiC}$ composites with hollow spherical microstructure were successfully fabricated by combustion synthesis. The microstructural evolution of the in-situ introduced $\mathrm{BN} / \mathrm{SiC}$ and its impacts on the properties of the obtained $\mathrm{Si}_{3} \mathrm{~N}_{4}-\mathrm{BN}-\mathrm{SiC}$ composites were studied. As the $\mathrm{B}_{4} \mathrm{C}$ content increases, the reaction temperature decreases and the porosity of sintered sample decreases evidently. Besides, the nitridation of $\mathrm{Si}$, phase transition from $\alpha-\mathrm{Si}_{3} \mathrm{~N}_{4}$ to $\beta-\mathrm{Si}_{3} \mathrm{~N}_{4}$, and growth of $\beta-\mathrm{Si}_{3} \mathrm{~N}_{4}$ grains are suppressed with the introduction of $\mathrm{B}_{4} \mathrm{C}$. Therefore, residual $\mathrm{Si}$ and $\alpha-\mathrm{Si}_{3} \mathrm{~N}_{4}$ are detected for samples prepared with high $\mathrm{B}_{4} \mathrm{C}$ content. The bending strength and Young's modulus of the obtained $\mathrm{Si}_{3} \mathrm{~N}_{4}-\mathrm{BN}$ $\mathrm{SiC}$ composites increase firstly and then decrease with the $\mathrm{B}_{4} \mathrm{C}$ content increasing because of the decreasing porosity and degradation of microstructure. Optimal mechanical properties with bending strength of $144 \mathrm{MPa}$, fracture toughness of $2.3 \mathrm{MPa} \cdot \mathrm{m}^{1 / 2}$, and Young's modulus of $54.5 \mathrm{GPa}$ are achieved when $\mathrm{B}_{4} \mathrm{C}$ content is $5 \%$ (in mass). 


\section{References:}

[1] WANG W D, YAO D X, CHEN H B, et al. $\mathrm{ZrSi}_{2}-\mathrm{MgO}$ as novel additives for high thermal conductivity of $\beta-\mathrm{Si}_{3} \mathrm{~N}_{4}$ ceramics. J. Am. Ceram. Soc., 2020, 103(3): 2090-2100.

[2] SUN S Y, XIE Z P, CHEN K X. Precisely controlled carbothermal synthesis of spherical $\beta-\mathrm{Si}_{3} \mathrm{~N}_{4}$ granules. Ceram. Int., 2020, 46(8): 10879-10884.

[3] HAMPSHIRE S. Silicon nitride ceramics-review of structure, processing and properties. J. Achieve. Mater. Manuf. Eng., 2007, 24(1): 43-50.

[4] LI X Q, YAO D X, ZUO K H, et al. Microstructure and gas permeation performance of porous silicon nitride ceramics with unidirectionally aligned channels. J. Am. Ceram. Soc., 2020, 103(11): 6565-6574.

[5] KALEMTAS A, TOPATES G, OZCOBAN H, et al. Mechanical characterization of highly porous $\beta-\mathrm{Si}_{3} \mathrm{~N}_{4}$ ceramics fabricated via partial sintering \& starch addition. J. Eur. Ceram. Soc., 2013, 33(9): $1507-1515$.

[6] YANG J G, WU P, ZHANG Y P, et al. Synthesis of $\mathrm{Si}_{3} \mathrm{~N}_{4}$ whiskers by rapid nitridation of silicon droplets. Int. J. Appl. Ceram. Technol., 2020, 17(1): 296-303.

[7] MATSUNAGA C, ZHOU Y, KUSANO D, et al. Nitridation behavior of silicon powder compacts of various thicknesses with $\mathrm{Y}_{2} \mathrm{O}_{3}$ and $\mathrm{MgO}$ as sintering additives. Int. J. Appl. Ceram. Technol., 2017, 14(6): 1157-1163.

[8] ZHI Q, WANG B, ZHAO S, et al. Synthesis and mechanical properties of highly porous ultrafine-grain $\mathrm{Si}_{3} \mathrm{~N}_{4}$ ceramics via carbothermal reduction-nitridation combined with liquid phase sintering. Ceram. Int., 2019, 45(17): 21359-21364.

[9] ZHANG Y, YU X, GU H, et al. Microstructure evolution and high-temperature mechanical properties of porous $\mathrm{Si}_{3} \mathrm{~N}_{4}$ ceramics prepared by SHS with a small amount of $\mathrm{Y}_{2} \mathrm{O}_{3}$ addition. Ceram. Int., 2021, 47(4): 5656-5662.

[10] CANO I G, BOROVINSKAYA I P, RODRIGUEZ M A, et al. Effect of dilution and porosity on self-propagating high-temperature synthesis of silicon nitride. J. Am. Ceram. Soc., 2002, 85(9): 2209-2211.

[11] LOJANOVÁ S, TATARKO P, CHLUP Z, et al. Rare-earth element doped $\mathrm{Si}_{3} \mathrm{~N}_{4} / \mathrm{SiC}$ micro/nano-composites- $\mathrm{RT}$ and HT mechanical properties. J. Eur. Ceram. Soc., 2010, 30(9): 1931-1944.

[12] LI X L, ZHANG L, YIN X, et al. Mechanical and dielectric properties of porous $\mathrm{Si}_{3} \mathrm{~N}_{4}-\mathrm{SiC}(\mathrm{BN})$ ceramic. J. Alloys Compd., 2010, 490(1/2): 40-43.

[13] WANG S J, JIA D C, YANG Z H, et al. Effect of BN content on microstructures, mechanical and dielectric properties of porous $\mathrm{BN} / \mathrm{Si}_{3} \mathrm{~N}_{4}$ composite ceramics prepared by gel casting. Ceram. Int., 2013, 39(4): 4231-4237.

[14] WANG S J, YANG Z H, DUAN X M, et al. Fabrication and characterization of in situ porous $\mathrm{Si}_{3} \mathrm{~N}_{4}-\mathrm{Si}_{2} \mathrm{~N}_{2} \mathrm{O}-\mathrm{BN}$ ceramic. Int. $J$. Appl. Ceram. Technol., 2014, 11(5): 832-838.

[15] KUSUNOSE T, SEKINO T, CHOA Y H, et al. Fabrication and microstructure of silicon nitride/boron nitride nanocomposites. $J$. Am. Ceram. Soc., 2002, 85(11): 2678-2688.

[16] ZHENG Y T, LI H B, ZHOU T. Microstructure and mechanical properties of h-BN-SiC ceramic composites prepared by in situ combustion synthesis. Mater. Sci. Eng. A-Struct., 2012, 540(1): 102-106.

[17] ZHANG Y, YAO D, ZUO K, et al. Fabrication and mechanical properties of porous $\mathrm{Si}_{3} \mathrm{~N}_{4}$ ceramics prepared via SHS. Ceram. Int., 2019, 45(12): 14867-14872.

[18] LI H B, ZHENG Y T, HAN J C. In-situ combustion synthesis of h-BN-SiC high-temperature ceramics. Key Eng. Mater, 2007, 353-358: 1501-1504.

[19] ZHANG Y, YAO D, ZUO K, et al. Effects of $\mathrm{N}_{2}$ pressure and $\mathrm{Si}$ particle size on mechanical properties of porous $\mathrm{Si}_{3} \mathrm{~N}_{4}$ ceramics prepared via SHS. J. Eur. Ceram. Soc., 2020, 40(13): 4454-4461.

[20] LAI K R, TIEN T Y. Kinetics of $\beta$ - $\mathrm{Si}_{3} \mathrm{~N}_{4}$ grain-growth in $\mathrm{Si}_{3} \mathrm{~N}_{4}$ ceramics sintered under high nitrogen pressure. J. Am. Ceram. Soc., 1993, 76(1): 91-96.

[21] RIEDEL R, KIENZLE A, DRESSLER W, et al. A silicoboron carbonitride ceramic stable to $2,000{ }^{\circ} \mathrm{C}$. Nature, 1996, 382(6594): 796-798.

[22] THIYAGARAJAN G B, DEVASIA R. Simple and low-cost synthetic route for $\mathrm{SiBCN}$ ceramic powder from a boron-modified cyclotrisilazane. J. Am. Ceram. Soc., 2019, 102(1): 476-489.

[23] YANG J F, ZHANG G J, OHJI T. Fabrication of low-shrinkage, porous silicon nitride ceramics by addition of a small amount of carbon. J. Am. Ceram. Soc., 2001, 84(7): 1639-1641.

[24] FABER K T, EVANS A G. Crack deflection processes- I . Theory. Acta Metall., 1983, 31(4): 565-576.

\section{原位引入 $\mathrm{BN}-\mathrm{SiC}$ 燃烧合成 $\mathrm{Si}_{3} \mathrm{~N}_{4}-\mathrm{BN}-\mathrm{SiC}$ 复合材料}

$$
\text { 张 叶 }{ }^{1,2} \text {, 姚冬旭 }{ }^{1} \text {, 左开慧 }{ }^{1} \text {, 夏咏锋 }{ }^{1} \text {, 尹金伟 }{ }^{1} \text {, 曾宇平 }{ }^{1}
$$

(1. 中国科学院 上海硅酸盐研究所, 高性能陶瓷和超微结构国家重点实验室, 上海 200050; 2. 中国科学院大学, 材料科学与光电工程中心, 北京 100049)

摘 要: $\mathrm{Si}_{3} \mathrm{~N}_{4}-\mathrm{BN}-\mathrm{SiC}$ 复合材料以其良好的力学性能和抗氧化性能而具有良好的工程应用前景。本研究以 $\mathrm{Si} 、 \mathrm{Si}_{3} \mathrm{~N}_{4}$ 稀释剂、 $\mathrm{B}_{4} \mathrm{C}$ 和 $\mathrm{Y}_{2} \mathrm{O}_{3}$ 为原料, 采用燃烧合成法成功制备了 $\mathrm{Si}_{3} \mathrm{~N}_{4}-\mathrm{BN}-\mathrm{SiC}$ 复合材料。通过 $\mathrm{Si} 、 \mathrm{~B}_{4} \mathrm{C}$ 和 $\mathrm{N}_{2}$ 气之间的 反应, 在 $\mathrm{Si}_{3} \mathrm{~N}_{4}$ 陶瓷中原位引入 $\mathrm{BN}$ 和 $\mathrm{SiC}$, 制备的 $\mathrm{Si}_{3} \mathrm{~N}_{4}-\mathrm{BN}-\mathrm{SiC}$ 复合材料由长棒状的 $\beta-\mathrm{Si}_{3} \mathrm{~N}_{4}$ 和空心球形复合材料 组成。实验研究了空心球微结构的形成机理, 结果表明, 生成的 $\mathrm{SiC} 、 \mathrm{BN}$ 颗粒及玻璃相覆盖在原料颗粒上, 当原料 颗粒反应完全时, 形成空心球形微结构。并进一步研究了 $\mathrm{B}_{4} \mathrm{C}$ 含量对 $\mathrm{Si}_{3} \mathrm{~N}_{4}-\mathrm{BN}-\mathrm{SiC}$ 复合材料力学性能的影响。原 位引入 $\mathrm{SiC}$ 和 $\mathrm{BN}$ 在一定程度上可以提高复合材料的力学性能。当 $\mathrm{B}_{4} \mathrm{C}$ 添加量为质量分数 $0 \sim 20 \%$ 时, 获得了抗弯 强度为 $28 \sim 144 \mathrm{MPa}$ 、断裂韧性为 $0.6 \sim 2.3 \mathrm{MPa} \cdot \mathrm{m}^{1 / 2}$, 杨氏模量为 $17.4 \sim 54.5 \mathrm{GPa}$ ，孔隙率为 $37.7 \% \sim 51.8 \%$ 的 $\mathrm{Si}_{3} \mathrm{~N}_{4}-\mathrm{BN}-\mathrm{SiC}$ 复合材料。

关 键 词: 燃烧合成; $\mathrm{Si}_{3} \mathrm{~N}_{4}-\mathrm{BN}-\mathrm{SiC}$ 复合材料; 原位引入; 相组成; 空心球; 形成机理

中图分类号: TQ174 文献标志码: A 